Irish Math. Soc. Bulletin

Number 83, Summer 2019, 19-27

ISSN 0791-5578

\title{
In the footsteps of Copernicus: Padua and Uppsala
}

\author{
STEFANO DE MARCHI AND MACIEJ KLIMEK
}

\begin{abstract}
For over half a millennium the life and work of the Polish astronomer and mathematician Nicolaus Copernicus has been described and discussed in countless publications. And yet there are some aspects of his life, as well as the whereabouts of his remains that are relatively unknown to the general public. One of the less explored episodes is the period Copernicus spent at Padua University in Italy. Another that deserves more recognition is the recent detective story, involving work at the University of Uppsala in Sweden to identify his genetic material, permitting the definitive location of his grave. In this article we intend to shed light on these less familiar facts about Copernicus, hoping that the reader will be enticed to visit those two amazing historical cities: Padua and Uppsala.
\end{abstract}

\section{INTRODUCTION}

Nicolaus Copernicus, or to use his Polish name Mikołaj Kopernik, was one of the very few scientists throughout history whose discoveries have had a profound impact not just on research but on human civilization in general. From the point of view of mathematicians, there are some rather specific aspects of his scientific contributions that make them timeless.

Most of all, his work is the first example how a better mathematical model of reality can dramatically improve comprehension of empirical data and significantly simplify forecasting. His work also exemplifies brilliantly how vital for science is liberation from blurring of the boundaries between extrinsic beliefs, mathematical models and reality.

Modern scientists function in an increasingly interdisciplinary research environment, very often held together by various mathematical constructions. Even within mathematics, gone are the days when different branches of the Queen of Science could happily exist in separation from each other. In this respect Copernicus, alongside other great figures of the Renaissance period, can also serve as a role model for the intellectuals of the 21 st century.

In this short article we would like to celebrate the varied educational background of Copernicus by conveying somewhat less known facts concerning his academic studies in Italy. In particular, while he studied mathematics and astronomy in Poland, there is some circumstantial evidence that the first draft of the heliocentric model was created during his medical studies in Padua. We will also describe the fascinating chain of events, which was a result of a cooperation of a Polish-Swedish team of archaeologists and experts in forensic medicine, and which lead to the identification of his remains just a few years ago. We are convinced that Copernicus, being himself a medical practitioner, would have loved the story.

2010 Mathematics Subject Classification. 01A99.

Key words and phrases. Copernicus, Kopernik, Padova, Padua, Uppsala.

Received on 12-6-2019. 


\section{Tangible evidence of Copernicus' Stay in Padua}

The several years that Copernicus spent in Italy were divided between four towns: Bologna (1496-1500), Rome (1500), Padua (1501-1504) and Ferrara (1503). In Ferrara he received a doctorate in canon law, which in fact was the main and official reason why he was studying in Italy. Here we want to focus on the time he spent at the University of Padua, which was not only the second oldest university in Italy (1222) and one of the oldest in the world, but also the most liberal one. That period of Copernicus' life is considered by his biographers to be the most obscure part of his stay in Italy (see for example in $[2$, p. 67$])$.

Copernicus studied mathematics and astronomy during the period 1491-1495 at the Jagiellonian University of Kraków in Poland, prior to his trip to Italy. It is important to mention that since the 13th century the cities of Padua and Kraków have had close links, and since the late 14th century this has been especially true of their universities. A sort of mutual esteem between their citizens, has made it natural for the students to move between the two universities to complete their studies. By the time Copernicus came to Padua to study medicine, the Polish presence in the city had been well established, and dates back at least to 1271 when Nicolaus de Polonia (Nicholas of Poland), a healer and later a dominican friar in Kraków, was appointed the rector of the University of Padua. Other prominent Poles were studying in Padua in the fifteenth century. Among them we should mention Maciej z Miechowa (Matthew of Miechów), called Miechowita, the renowned author of the treatise De duabus Sarmatiis. Moreover in 1487 Jan Ursinus, the author of Modus epistolandi, studied medicine there. This indicates that when Copernicus arrived in Padua, he was following a well-established tradition of bilateral contacts and most likely it was easy for him to integrate with the academic community.

As another manifestation of this tradition, in 1873, on the occasion of the fourth centenary of Copernicus' birth, the University of Padua dedicated to him the inscription:

NIC. COPERNICO

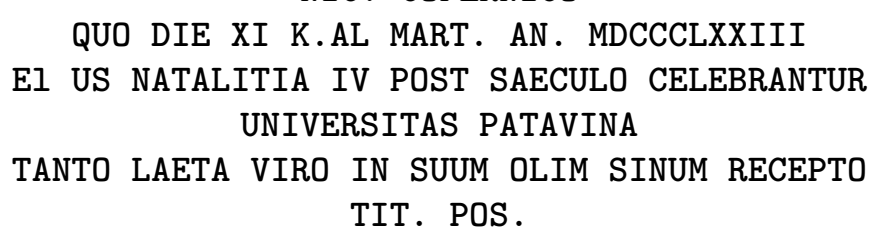

This is positioned on the right-hand side wall in the great-hall of the University, located in the Palazzo Bo, the main building that has hosted the rectorate since the fifteenth century. The plate, in the form of golden characters on a black background (see Fig. 1 ), is surrounded by other plates donated to the University by students after they completed their studies Fig. 2.

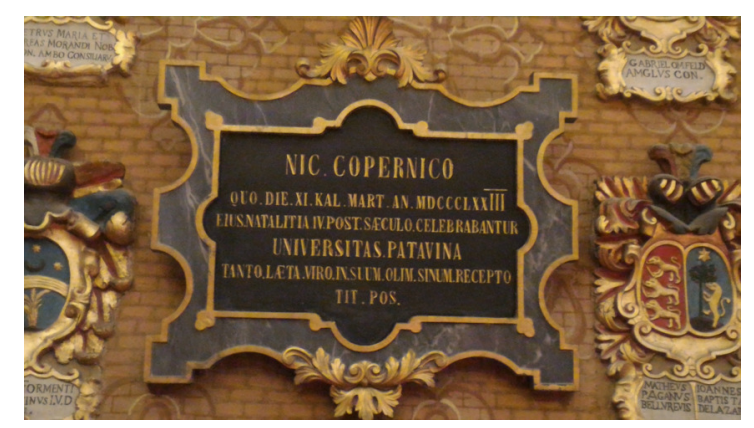

FiguRE 1. Inscription on the right wall of the great-hall of the University of Padua (Photo courtesy of the University of Padua) 
Unfortunately there are no written sources directly concerning Copernicus' stay in Padua. In fact, for centuries the biographers of Copernicus could not provide any tangible evidence. Eventually, in 1876 a document certifying his diploma in canon law was found. The document was issued by the University of Ferrara in May 1503, confirming that prior to his studies in Ferrara Copernicus had studied for three years in Padua. This is detailed in the informative book by Bierkenmajer [1], published on the occasion of the seventh centenary of the foundation of the Polish Art and Science Academy of the University of Padua.

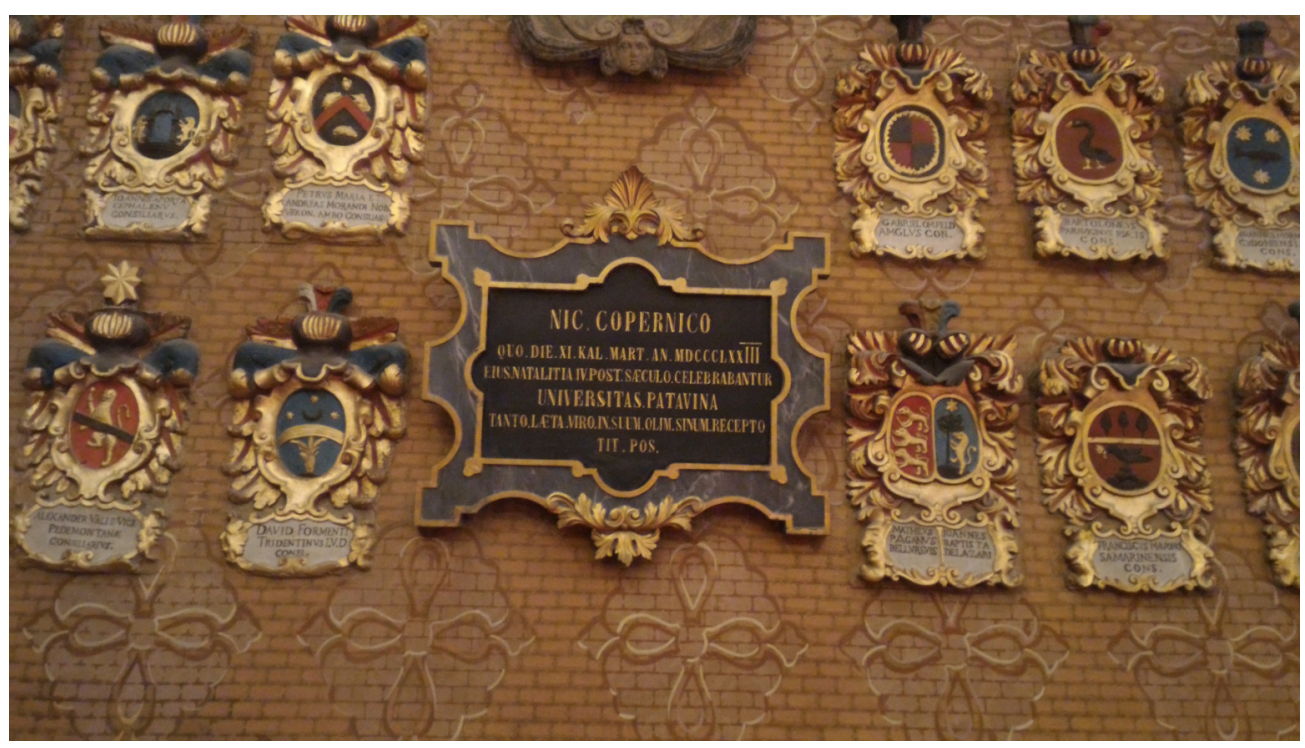

Figure 2. The Copernicus plate surrounded by plates donated to the University by students (Photo courtesy of the University of Padua)

During Copernicus' stay in Padua, officially he was studying medicine, but it is safe to assume that he was constantly in contact with the astronomers, mathematicians and philosophers around him. According to [1], the great Hellenistic philosopher Niccolò Leonico Tomeo had a particularly strong influence on Copernicus, to the extent that when Tomeo moved to Venice, Copernicus decided that it was time to return to Poland. It is very likely that the stimulating academic environment that he found in Padua, allowed him to formulate in writing a short outline his heliocentric theory of the world, either during his stay in Italy or shortly afterwards. The earliest evidence of the existence of the manuscript known as Commentariolus (A Little Commentary) comes from an inventory of the book collection belonging to Matthew of Miechów (see e.g. [4]). The inventory was compiled in 1514, when Matthew of Miechów was a professor and a rector of the Jagiellonian University of Kraków. Interestingly, while handwritten copies of Commentariolus were circulating during the best part of the sixteenth century, later the treatise fell into complete obscurity, to be eventually published in the nineteenth century.

No signs of the actual house in Padua where Copernicus stayed have been found. However, there exists a document from that time found in the book of deeds of the notary Stefano Venturato, TOMO 1 degli istrumenti depicted in Fig. 3, which determines Copernicus' whereabouts. The deed is a proxy issued to the canons Apicio Colo and Michele Iode of Wrocław's church, to take possession in his name of the scolasteria at the Collagiate Church of the Holy Cross in the same city. The date of this deed is 10 January 1503 and was written following instructions of Copernicus. Since the deed 
was initiated by a member of the clergy, it was written at the Padua bishop's chancery in front of two priests - father Leonardo Redinger of the diocesis of Padua and father Niccolò Monsterberg of the diocesis of Wrocław (in the deed written as Vradislavia). The document, Fig. 3, can be seen and consulted at the State Archive in Padua (the address is Via dei Colli, 24 - Padova), in the volume 2245, f. 175 (f. stands for "folio", that is page). In [5] the page is 173, but as you see from Fig. 3 is indeed 175.

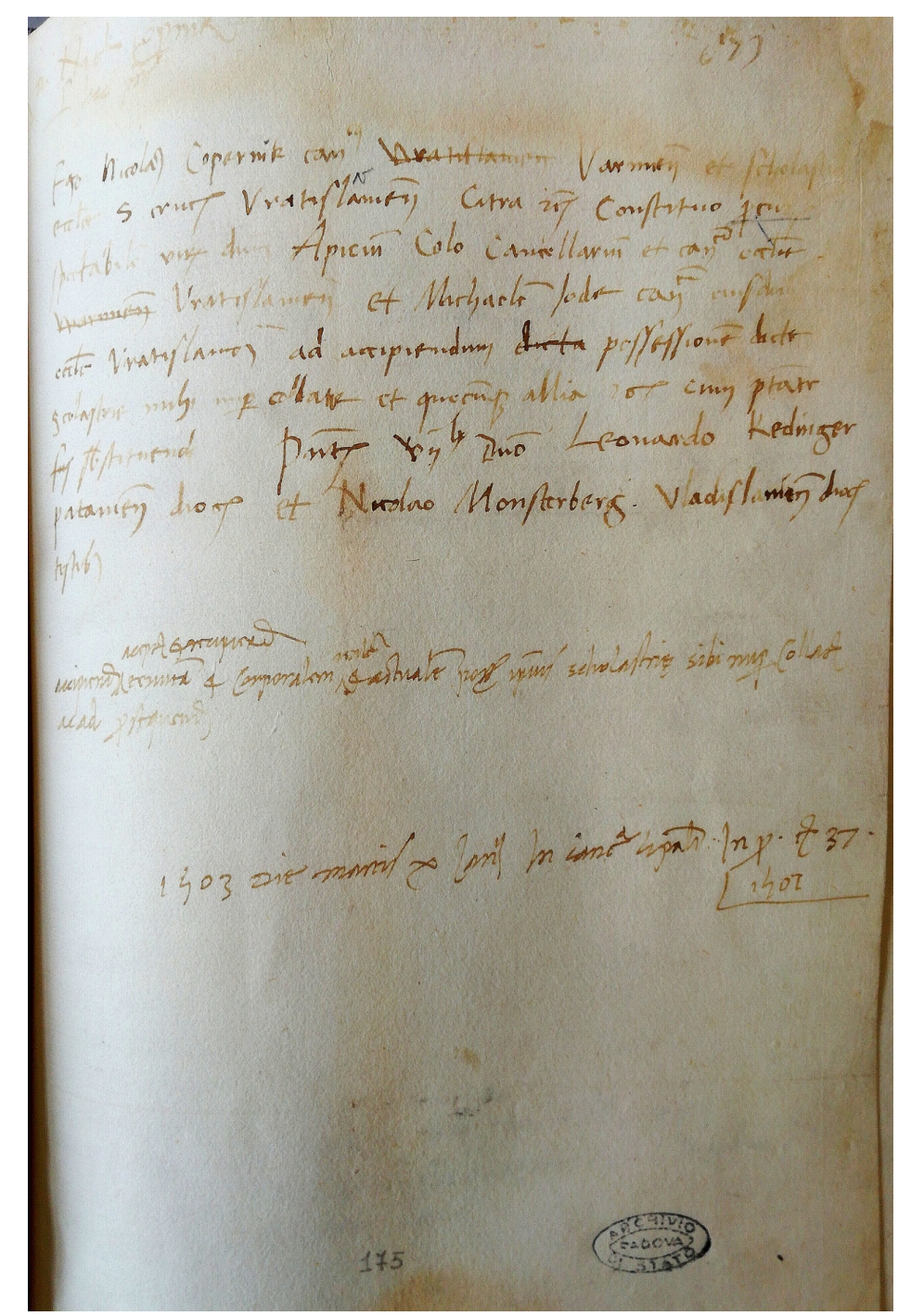

Figure 3. The deed signed by Copernicus. The paper is at the State Archive of Padua, Notary Archive Vol. 2245, f. 175 (Photo courtesy of the Archivio Notarile - Padova)

The deed in Latin says the following:

Procura reverendi domini Nicolai Copernik Per hoc presens*** Ego Nicolaus Copernik, canonicus Varmiensis et scholasticus ecclesie Sancte Crucis Vratislaviensis citra et cetera, constituo procuratores spectabilem virum dominum Apicium Colo, cancellarium et canonicum ecclesie Vratislaviensis, et Michaelem Iode, canonicum eiusdem ecclesie Vratislaviensis, ad accipiendum possessionem diete scolastrie mihi nuper 
coliate et quecumque allia et cetera cum potestate substituendi. Presentibus venerabili domino Leonardo Redinger Pataviensis diocesis et Nicolao Monsterberg Vladislaviensis diocesis

testibus accipiendum, aceptandum et recipiendum tenutam et corporalem, realem et actualem possessionem ipsius scholastrie sibi nuper collatae ac ad prosequendum.

1503, die martis $x$ ianuarii, in cancellaria episcopali. In prothocollo, charta 37, 1502.

This document is very important: before it was uncovered there had been only hypotheses, but not a real proof of the whereabouts of the astronomer during those years.

\section{The Polish-Swedish Detective Story}

Someone familiar with any of the published biographies of Copernicus might be justifiably wondering what could be his possible connection to Sweden, a country never visited by the great astronomer. In order to explore that link, we need to move back in time to a small medieval fishing town situated on the Vistula Lagoon in Northern Poland called Frombork (known also by its German name as Frauenburg). It was there that Copernicus had lived for over three decades prior to his death in 1543. It was also there that he wrote his groundbreaking work De revolutionibus orbium coelestium. For a long time it was assumed that Copernicus, who had served as a lay canon at the Frombork cathedral - was buried inside the church itself, under the floor, in an unmarked grave. Some historians suspected that the grave was located next to the altar of the Holy Cross for the maintenance of which Copernicus himself was responsible (see [7] and [8]). However, before explaining how we know that this is indeed the case we have to take a short historical detour to explain how through the trials and tribulations of history a Swedish thread is interwoven into the Copernican legacy.

To this end, we have to move forward in time to the year 1587. After a coronation ceremony at the end of that year, Sigismund III Vasa became the King of Poland and the Grand Duke of Lithuania. This was the beginning his 45 year long rule of the PolishLithuanian Commonwealth, which lasted right until his death. Sigismund III Vasa was the son of the king of Sweden Johan III and a Polish-Lithuanian princess Catherine Jagiellon. Being the only male offspring of that union, he was also the crown prince of Sweden and inevitably inherited the Swedish throne upon the death of his father in 1592. However, his reign in Sweden was cut short in 1599 when he was deposed by his own uncle acting in collusion with the early incarnation of the Swedish parliament. This marks the beginning of an especially dark period in the history of Polish-Swedish relations. Over the next six decades Poland and Sweden endured five wars with cumulative duration of approximately 25 years. During one of these wars, in 1626 the Swedish troops attacked and subsequently occupied Frombork, causing significant loss of human life and substantial material destruction. In particular, the cathedral treasury was robbed. The loot taken back to Sweden included a priceless collection of books which Copernicus left behind when he died. The fate of his astronomical instruments is uncertain, but 22 of his books ended up at Uppsala University in Sweden. 


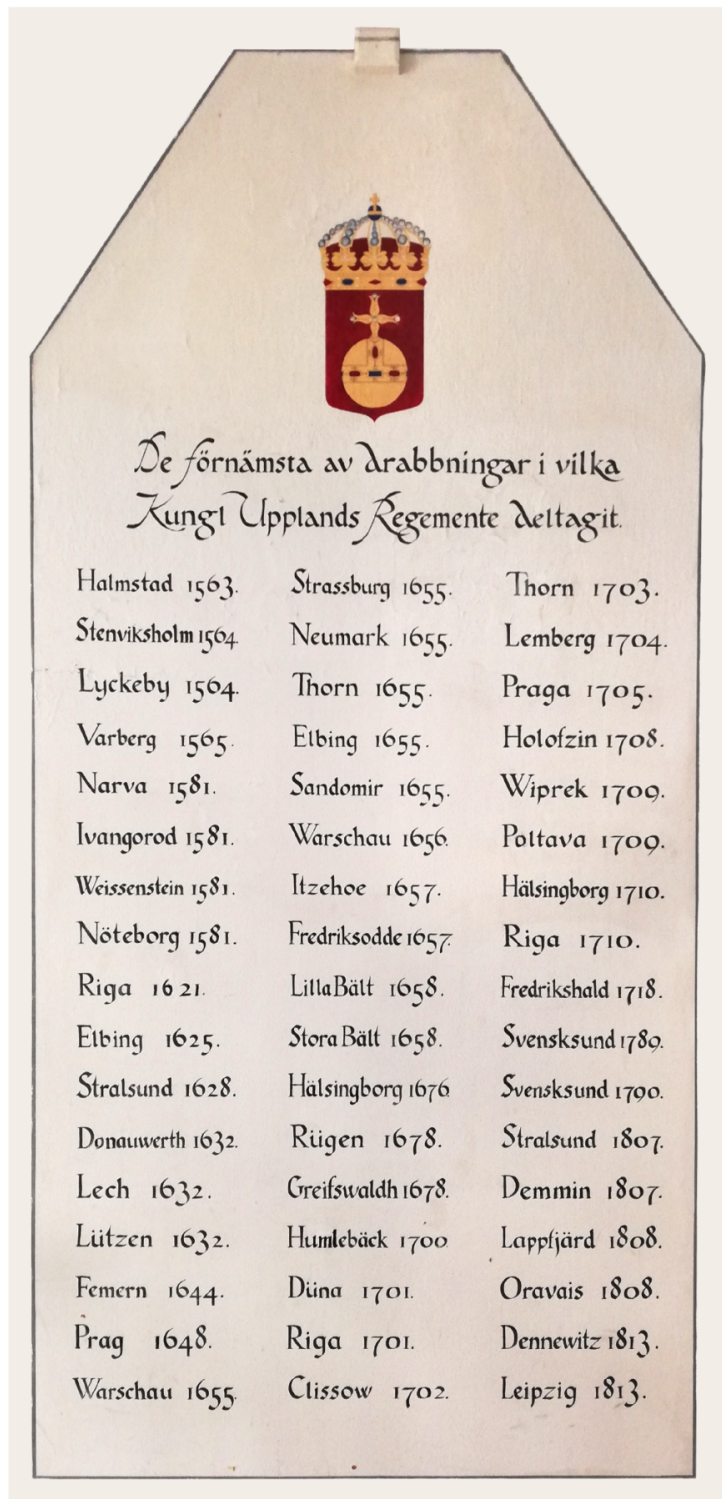

FIgURE 4. Inscription at Uppsala University (Photo by M. Klimek)

The traces of these Polish-Swedish conflicts can be still found today. For example, the Mathematics Department of Uppsala University was housed until recently in a group of buildings inherited from the Uppland Regiment, a Swedish army infantry unit established in the middle of 16th century and disbanded only in 1957. In one of those buildings, to this day one can find a large wall inscription commemorating major battles fought by the regiment. As shown in Figure 4, fair share of the locations included on this list were in Poland. The place where the former barracks are situated is known as Polacksbacken. According to the prominent 17th century Uppsala University professor Johannes Schefferus, the name originates form the fact that Polish soldiers serving under Sigismund III Vasa set their camp there. More pertinent to our story is the fact that the Uppsala University library Carolina Rediviva is still in possession of some old books which made their way to Sweden in the 17th century, courtesy of Swedish troops returning home with their spoils of war. For centuries, the 22 books that used to belong to Copernicus remained in total obscurity, buried among other old books and 
documents stored at Uppsala University. A change of their status came about just over a decade ago.

In 2004, the Polish bishop Jacek Jezierski from the Warmian Cathedral Chapter, who was also at the time the provost of the Frombork's Archcathedral, asked a prominent archaeologist professor Jerzy Gąssowski if he would be interested in trying to locate the remains of the great astronomer. Knowing that the vast cathedral church hides over a hundred mostly anonymous graves, the archaeologist initially declined the undertaking [8]. It should be mentioned that there had been earlier unsuccessful attempts - the first one was ordered by Napoleon himself in 1807 [3]. The bishop however did not give up and told Gąssowski about a theory posited by the historian Jerzy Sikorski, according to which canons were buried close to the altars for the upkeep of which they had been responsible. Working on this assumption would narrow down the search to a manageable fragment of the church. In the end, the professor relented. As a consequence, the archaeological quest commenced in 2004 and continued on and off until 2006 [8]. The initial results seemed very promising. The researchers found the remains of a man of the right age, with well preserved cranium, but no mandible, and a handful of other bones. On the basis of the cranium a scientist from the Central Forensic Laboratory at the Polish Police Headquarters, inspector Dariusz Zajdel, reconstructed the face of the deceased, which according to anthropologists showed significant likeness to existing portraits of the astronomer [7, 8, 10]. Even so, all this was at best only circumstantial evidence for the claim that the grave of Copernicus was identified.

In October 2006, a serendipitous cultural event in Uppsala marked the beginning of the process of finding an empirical justification of this claim. As part of celebrations of the so called Polish Days in Sweden, Museum Gustavianum in Uppsala organised an exhibition showing astronomical instruments from the time of Copernicus on loan from the Jagiellonian University in Kraków. It also displayed some of the old books mentioned earlier. The opening address was given by professor Gąssowski and generated a considerable interest among the audience. In particular, two professors from Uppsala University, the astronomer Göran Henricksson and the archaeologist Władysław Duczko, suggested getting in touch with their university colleague who was a renowned expert in forensic and historical DNA analysis. The person they had in mind was a professor in forensic medicine named Marie Allen, who as it turned out was very much interested in the challenge.

Among the remains recovered, a few molars as well as the femur bones contained viable genetic material, and the mitochondrial DNA analysis confirmed they all came from the same individual [3]. The tests were done independently by professor Allen, professor Wiesław Bogdanowicz from the Polish Academy of Science in Warsaw and two forensic geneticists from Kraków Dr. Andrzej Beanicki and Dr. Tomasz Kupiec. This did not however answer the question about the identity of the deceased, as an extensive search for DNA from contemporary relatives of Copernicus or their descendants turned out to be a dead end. Luckily, one of Copernicus' books in the Uppsala University collection, namely Calendarium Romanum Magnum (see Figure 5) contained 2 hair strands with enough workable DNA to perform comparative analysis. The results finally confirmed that the remains belong to Copernicus and his grave has been located.

\section{Final REMARKS}

While admiring the truly Renaissance aspects of the Copernicus legacy and the wonderful diversity of the modern science that helped to unravel the mystery of the astronomer's grave, it is only fitting to close our story with a quotation from De revolutionibus orbium coelestium [6] expressing the great astronomer's motivation for undertaking research: 


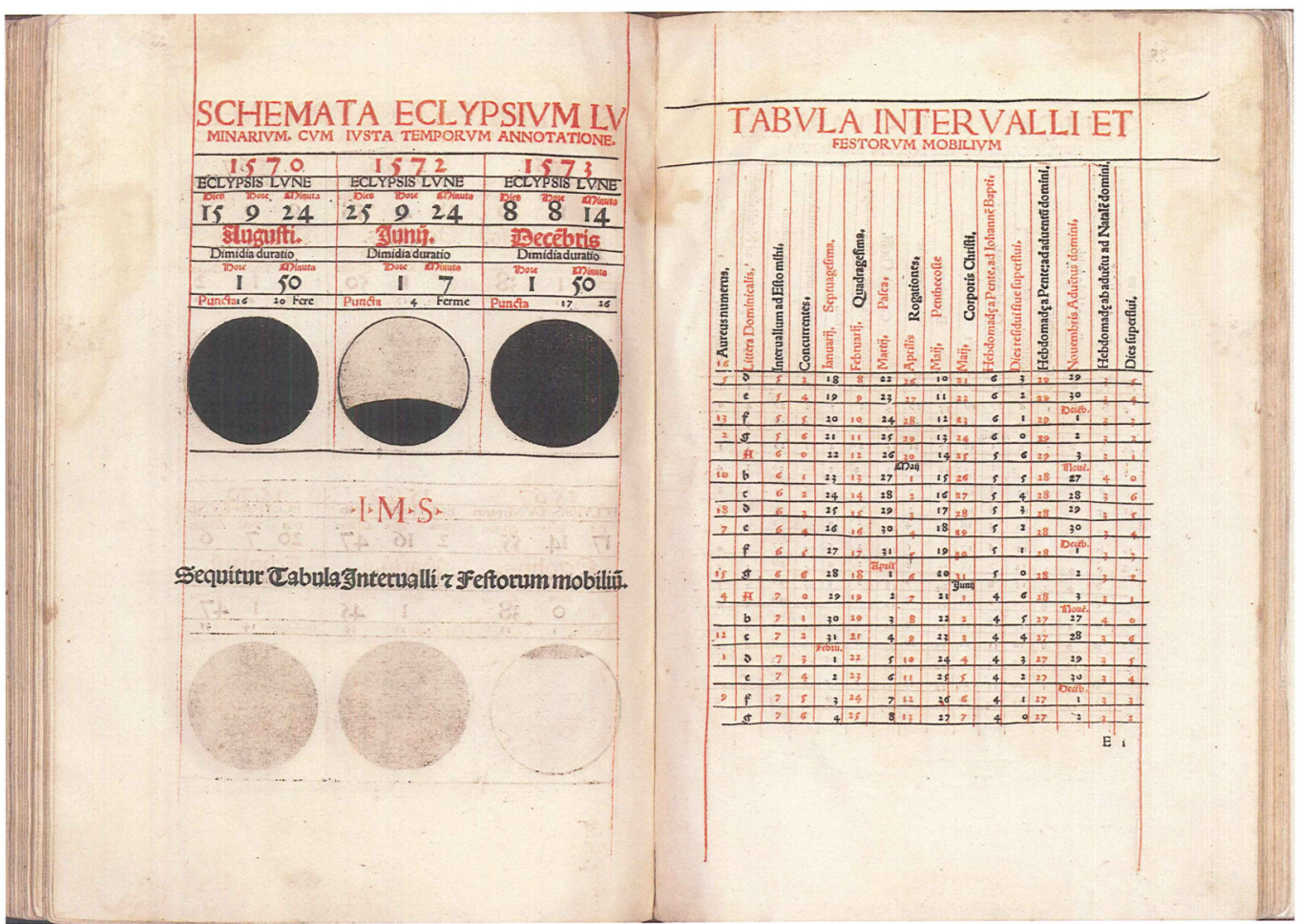

Figure 5. Pages from Kopernik's own copy of Calendarium Romanum Magnum (Scan courtesy of the Uppsala University Library)

Among the many various literary and artistic pursuits which invigorate men's minds, the strongest affection and utmost zeal should, I think, promote the studies concerned with the most beautiful objects, most deserving to be known. [...] What indeed is more beautiful that heaven, which of course contains all things of beauty?

\section{REFERENCES}

[1] L. Birkenmajer, Niccoló Copernico e l'Università di Padova, in Omaggio dell'Accademia di scienze e lettere polacca all'Università di Padova nel settimo centenario dalla sua fondazione, Cracovia 1922.

[2] Bronisław Biliński: Messaggio e itinerari copernicani, Accademia Polaco delle Scienze e Biblioteca del Centro di studi a , Conferenze 97, pp. 208.

[3] Wiesław Bogdanowicz, Marie Allen, Wojciech Branicki, Maria Lembring, Marta Gajewska, and Tomasz Kupiec, Genetic identification of putative remains of the famous astronomer Nicolaus Copernicus, Proceedings of the National Academy of Sciences, vol 106, no. 30, 12279-12282 (July 28, 2009).

[4] Jerzy Dobrzycki and Lech Szczucki, On the transmission of Copernicus's Commentariolus in the sixteenth century, Journal for the History of Astronomy, 20 (1989), 25-28.

[5] Erice Rigoni: Un autografo per Niccolò Copernico, Quaderni per la storia dell' Università di Padova nr. 16 (1983).

[6] Nicholas Copernicus Complete Works Vol. 2: Nicholas Copernicus on the Revolutions, Translation and commentary by Edward Rosen, Editor: Jerzy Dobrzycki; pp. 1-450, The Macmillan Press Ltd, London, 1978.

[7] Owen Gingerich, The Copernicus grave mystery, Proceedings of the National Academy of Sciences, vol 106, no. 30, 12215-12216 (July 28, 2009).

[8] Justyna Hofman-Wiśniewska, Two strands of Kopernik's hair - an interview with professor Jerzy Gassowski (in Polish), In: Sprawy Nauki, Nr 11-12(136) (2008). (Available on line at http://www.sprawynauki.edu.pl/archiwum/dzialy-wyd-papierowe/245-archeologia/885-dwawosy-kopernika 
[9] Luigi Pepe (Editor) Copernico e lo Studio di Ferrara. Università, dottori e studenti. pp. 1-154, Cooperativa Libraria Universitaria Editrice Bologna, Bologna 2003.

[10] Dariusz Zajdel, Did Mikotaj Kopernik look like this? (in Polish) Central Forensic Laboratory of the Polish Police, http://clk.policja.pl/clk/badania-i-projekty/ciekawe-badania/10826.

Stefano De Marchi is a numerical analyst at the Department of Mathematics "Tullio LeviCivita" of the University of Padua, Italy. His main research interests are in multivariate polynomial and radial basis functions approximation. He has also published articles on applications of mathematics to medical imaging, wine description and recently also on mathematical curiosities.

Maciej Klimek is a mathematican working at Uppsala University in Sweden. His main research interests lie in pluricomplex analysis and especially pluripotential theory. He has also published articles on functional analysis, time series analysis, financial mathematics and computer graphics.

(S. De Marchi) Department of Mathematics "Tullio Levi-Civita”, University of Padova, I-35121 PADOVA, ITALY

(M. Klimek) Department of Mathematics, Uppsala University, P.O.Box 480, 751-06 UppSALA, SWEDEN

E-mail address: demarchi@math.unipd.it, maciej.klimek@math.uu.se 